\title{
FAKTOR-FAKTOR YANG MEMPENGARUHI MOTIVASI BERPRESTASI MAHASISWA
}

\author{
Rabukit Damanik \\ Dosen STKIP Budi Daya Binjai
}

\begin{abstract}
ABSTRAK
Motivasi berprestasi merupakan daya penggerak untuk mencapai taraf prestasi belajar yang setinggi mungkin demi pengharapan kepada dirinya sendiri. Motivasi berprestasi dipengaruhi oleh dua faktor yaitu faktor intern dan ekstern. Ciri-ciri seseorang yang memiliki motivasi berprestasi tinggi antara lain : a) Mempunyai keinginan untuk bersaing secara sehat dengan dirinya sendiri maupun dengan orang lain, b) Mempunyai keinginan bekerja dengan baik, c) Berfikir realistis, tahu kemampuan serta kelemahan dirinya, d) Memiliki tanggung jawab pribadi, e) Mampu membuat terobosan dalam berpikir, Berpikir strategis dalam jangka panjang, f) Selalu memanfaatkan umpan balik untuk perbaikan.

Tujuan penelitian ini adalah untuk mengetahui factor-faktor yang mempengaruhi motivasi berprestasi mahasiswa. Populasi dalam penelitian ini adalah mahasiswa Prodi Administrasi Pendidikan STKIP Budi Daya Binjai sebanyak 35 orang. Hasil penelitian menunjukkan pengaruh kepemimpinan terhadap motivasi berprestasi mahasiswa sebesar $0,184(18,4 \%)$ pada taraf $\alpha=0,05$.
\end{abstract}

\section{Kata Kunci : Kepemimpinan, Motivasi, Berprestasi, Mahasiswa}

\section{PENDAHULUAN}

Pendidikan merupakan salah satu upaya untuk membangun dan meningkatkan mutu sumber daya manusia menuju era globalisasi yang penuh dengan tantangan sehingga disadari bahwa pendidikan merupakan sesuatau yang sangat fundamental bagi setiap individu.. Mahasiswa dalam menempuh perkuliahan di perguruan tinggi sangat membutuhkan motivasi berprestasi dalam memperoleh pengetahuan, nilai-nilai, dan keterampilan yang berhubungan dengan keilmuannya. Dimana setiap individu memiliki kondisi internal yang berperan dalam aktivitas dirinya sehari-hari. Salah satu kondisi internal tersebut adalah motivasi.

Motivasi adalah dorongan yang timbul dalam diri seseorang untuk bertingkah laku. Dorongan ini berada pada diri seseorang yang menggerakkan untuk melakukan sesuatu yang sesuai dengan dorongan dalam dirinya. Bentuk dorongan pada manusia bermacam-macam seperti dorongan belajar, dorongan kerja dan dorongan untuk berprestasi. Motivasi yang menjadi fokus dalam penelitian ini adalah motivasi berprestasi.
Motivasi berprestasi itu bisa diberbagai bidang, seperti dibidang akademik, pekerjaan, organisasi.

Salah satu keberhasilan mahasiswa dalam pendidikan ditunjukkan dengan prestasi akademiknya. Pada kenyataannya ditemukan tuntutan prestasi akademik pada mahasiswa semakin tinggi sementara daya belajarnya biasabiasa saja. Hal inilah yang menyebabkan tingkat keberhasilan mahasiswa dalam prestasi akademik kurang sebagaimana diharapkan oleh pihak kampus, orang tua dan mahasiswa itu sendiri. Fungsi pendidikan salah satunya adalah membentuk sikap dan orientasi mahasiswa terhadap belajar, menanamkan sikap positif dan pengetahuan serta untuk mengembangkan keterampilan belajar secara efektif. Hasil pengamatan awal yang dilakukan, peneliti menemukan motivasi berprestasi dibidang akademik pada mahasiswa Prodi Administrasi Pendidikan STIKIP Budi Daya Binjai masih sangat kurang.

Motivasi itu sendiri dapat dibagi menjadi dua bagian, yaitu motivasi instrinsik dan motivasi ekstrinsik. Motivasi instrinsik merupakan dorongan atau keinginan yang muncul dari dalam diri seseorang berupa; minat, cita-cita, dan lain-lain. 


\section{Jurnal Serunai Administrasi Pendidikan Vol 9, No. 1, Maret 2020 e-ISSN 2620-9209}

Sedangkan motivasi ekstrinsik merupakan dorongan atau keinginan yang muncul dari luar diri seseorang bisa berupa; dari guru, dari orang tuanya, dari temannya, dari upah, lingkungan dan lain- lain. Di dalam motivasi berprestasi ini ada beberapa faktor yang memberikan pengaruh, di antaranya; 1) Motivasi instrinsik: a) minat, b) cita-cita, 2) Motivasi ekstrinsik: kepemimpinan, upah, lingkungan (sarana dan prasarana, penasehat akademik, iklim kerja), dan lain-lain.

Keberhasilan mahasiswa dalam pendidikannya juga dipengaruhi oleh motivasi berprestasi yang dimiliki. Motivasi berprestasi sebagai daya dorong yang memungkinkan seseorang berhasil mencapai apa yang diidamkan. Seseorang yang memiliki motivasi berprestasi tinggi cenderung untuk selalu berusaha mencapai apa yang diinginkan walaupun mengalami hambatan dan kesulitan dalam meraihnya. Pada kenyataannya motivasi berprestasi yang dimiliki mahasiswa cenderung sering mengalami penurunan dan di waktu lain mengalami peningkatan. Motivasi berprestasi yang dimiliki mahasiswa idealnya selalu mengalami kemajuan sehingga akan mempercepat apa yang diidamkan. Hal inilah yang belum dimiliki oleh generasi muda untuk selalu meningkat motivasi berprestasinya.

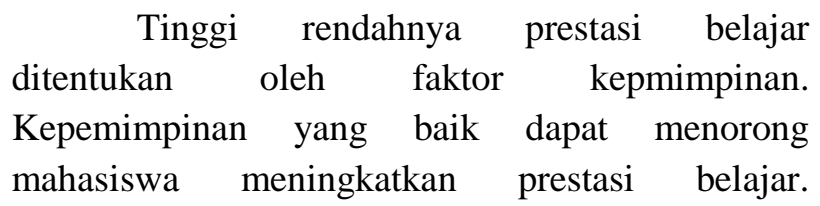
Kepemimpinan merupakan kemampuan seseorang yang menduduki jabatan sebagai pemimpin untuk memimpin yang terdiri dari mengarahkan, membimbing dan mempengaruhi sesuatu perilaku orang yang dipimpin untuk berfikir dan bertindak seemikian rupa melalui perilaku yang positif guna menapai tujuan. Seorang pemimpin sebaiknya mempunyai kemampuan dalam memimpin yang dapat menunjang terapainya tujuan yang diaharapkan. Kepemimpinan merupakan suatu kemampuan dan kesiapan yang harus dimiliki oleh eseorang untuk mempengaruhi, membimbing dan mengarahkan atau mengelola peserta didiknya agar mereka mau berbuat sesuatu demi terapainya tujuan pembelajaran.

Kepemimpinan dalam pembelajaran lebih berorientasi pada: 1. Proses bagaimana kualitas pembelajaran mengalami peningkatan dari waktu ke waktu. 2. Menggerakkan mahasiswa mencapai kompetensi dasar semaksimal mungkin. 3. Penumbuhan motivasi internal belajar anak didik. Ketiga orientasi tersebut tidak terjadi secara terpisah-pisah. Target akhir kepemimpinan pembelajaran adalah dosen mampu menumbuhkan motivasi (internal motivation) internal belajar anak didik, yang selanjutnya menjadi penggerak (drive) bagi anak didik untuk secara mandiri (self motivation) berupaya (dosen sekedar fasilitator, mediator, reseources linker, advisor) dalam mencapai kompetensi dasar pada dirinya secara maksimal sebagai bentuk kualitas pembelajarannya.

\section{Motivasi Beprestasi}

Menurut Huston (1985) motivasi tertuju pada faktor-faktor: permulaan (initiation), arah (direction), intensitas (intensity) dan ketekunan (persistency). Faktor-faktor tersebut menentukan sikap tingkah laku yang diinginkan. Sedangkan Baron \& Greenberg (1990) dalam teorinya "Expectancy Theory" adalah hasil dari tiga keyakinan yang dimiliki setiap orang yang meliputi : (a) expectancy, percaya bahwa setiap usaha akan membuahkan hasil atau prestasi, (b) instrumentally, percaya bahwa setiap prestasi akan dihargai atau mendapat imbalan, dan (c) valence, penghargaan atau imbalan bernilai bagi penerima.

Murray (dalam Chaplin, 2004) mendefinisikan motivasi berprestasi sebagai motif untuk mengatasi rintangan-rintangan atau berusaha melaksanakan secepat dan sebaik mungkin pekerjaan yang ada. Selain itu menurut McClelland, Atkinson, Clark, \& Lowell (dalam Meinawati, 2007) motivasi berprestasi merupakan tujuan dari individu agar berhasil dalam persaingan dengan standar tinggi. Individu mungkin gagal mencapai tujuan ini, tetapi memungkinkan individu tersebut untuk mengidefikasikan tujuan yang akan dicapai. 
McClelland (1987) menunjukkan bahwa motif yang kuat untuk berprestasi atau keinginan untuk berhasil atau unggul dalam situasi persaingan, berhubungan dengan sejauh mana individu dimotivasi untuk menjalankan tugasnya dan teori motivasi ini dibagi menjadi motif akan prestasi, motif akan afiliasi dan motif akan kekuasaan. Teori ini mengatakan bahwa orang yang dengan kebutuhan prestasi yang tinggi suka memikul tanggung jawab untuk pemecahan masalah, mereka cenderung menetapkan masalahmasalah yang agak sulit untuk diri mereka sendiri dan memperhitungkan resiko untuk mencapai tujuan-tujuan tersebut dan sangat dimotivasi oleh situasi kerja yang bersaing dan penuh tantangan.

Motivasi mempunyai empat pengaruh penting dalam pembelajaran, yang tiga diantaranya (a) motivasi memberikan semangat mahasiswa, mahasiswa menjadi lebih aktif, sibuk dan tertarik, motivasi menompang upayaupaya dan menjaga (belajar) mahasiswa tetap jalan, (b) motivasi mengarahkan dan mengendalikan tujuan, mahasiswa mengarah untuk melengkapi suatu tugas, mencapai tujuan yang diinginkan, (c) motivasi dapat menentukan kegiatan apa yang akan dilakukan dan bagaimana tugas-tugas itu akan dilakukan. Motivasi merupakan penentu prioritas untuk keberhasilan seseorang. Dikatakan penentu prioritas karena (a) motivasi merupakan motor penggerak dari setiap kebutuhan yang akan dipenuhi, (b) menentukan tujuan yang hendak dicapai, dan (c) menentukan perbuatan yang harus dilakukan.

Menurut Mc.Clelland (1987) menyatakan bahwa indikator motivasi adalah sebagai berikut: (1) Kebutuhan untuk berprestasi (need for achievement), Kebutuhan untuk berprestasi merupakan daya penggerak yang memotivasi semangat kerja seseorang untuk mengembangkan kreativitasnya dan mengarahkan kemampuannya demi mencapai prestasi kerja yang maksimal. Seseorang yang menyadari bahwa hanya dengan mencapai prestasi kerja yang tinggi akan memeroleh. pendapatan yang besar, sehingga dapat memenuhi kebutuhan yang diperlukan; (2)
Kebutuhan berafiliasi (need for affiliation), Merupakan keinginan memiliki kebutuhan untuk bersosialisasi dan ineraksi dengan individu lain. Kebutuhan ini mengarahkan tingkah laku untuk mengadakan hubungan dengan orang lain; dan (3) Kebutuhan kekuatan (need for power), Merupakan daya penggerak yang memotivasi semangat kerja seseorang dengan mengarahkan semua kemampuan demi mencapai kekuasaan atau kedudukan yang terbaik di dalam organisasi. Ego manusia ingin lebih berkuasa dari manusia lainnya akan menimbulkan persaingan. Persaingan ditumbuhkan secara sehat oleh atasan agar bawahannya termotivasi untuk bekerja lebih giat.

Menurut McClelland dan Atkinson (dalam Rahmawati, 2006), motivasi yang paling penting untuk pendidikan adalah motivasi berprestasi, dimana seseorang cenderung berjuang untuk mencapai sukses atau memilih suatu kegiatan yang berorientasi untuk tujuan sukses atau gagal. McClelland juga mengemukakan bahwa orang yang memiliki motivasi berprestasi yang tinggi akan lebih memperhatikan hal-hal yang berhubung.

Faktor kepemimpinan memegang peranan yang penting karena pemimpin itulah yang akan menggerakkan dan mengarahkan organisasi dalam mencapai tujuan dan sekaligus merupakan tugas yang tidak mudah. Menurut Sagala (2009) kepemimpinan berasal dari kata pemimpin, maksudnya adalah orang yang dikenal oleh dan berusaha mempengaruhi para pengikutnya untuk merealisir visinya. Sedangkan Yulk (1997) kepemimpinan adalah proses menghargai orang lain untuk memahami dan menyepakati tentang apa yang perlu untuk dilakukan dan bagaimana hal tersebut dapat dilaksanakan secara efektif, dan proses memfasilitasi usaha individu atau kelompok (kolektif) untuk memenuhi tujuan-tujuan utama.

Kepemimpinan adalah sebuah hubungan yang saling mempengaruhi di antara pemimpin dan pengikut yang menginginkan perubahan nyata yang mencerminkan tujuan bersamanya. Menurut Fullan (2004) "Leadership is not mobilising others to solve the problem, because they know how to solve, but they help them cope with the problem, which is not 
successfully resolved". Artinya kepemimpinan tidak memobilisasi orang lain untuk memecahkan masalah, karena mereka tahu bagaimana menyelesaikannya, tapi membantu mereka mengatasi masalah, yang tidak berhasil diselesaikan. Colquitt at. al. (2009) menyatakan kepemimpinan didefinisikan sebagai penggunaan kekuasaan dan pengaruh untuk mengarahkan aktivitas pengikut terhadap pencapaian tujuan.

Northouse (2013) menyatakan "despite the multitude of ways in which leadership has been conceptual alized, the following components can be identified as central to the phenomenon: (a) leadership ia a process, (b) leadership involves influence, (c) leaderships occurs in groups, (d) leadership involves common goals". Artinya bahwa "terlepas dari banyaknya cara di mana kepemimpinan telah diimplementasikan secara konseptual, komponen berikut dapat diidentifikasi sebagai inti dari fenomena ini: (a) kepemimpinan adalah sebuah proses, (b) kepemimpinan melibatkan pengaruh, (c) kepemimpinan terjadi dalam kelompok, (d ) kepemimpinan melibatkan tujuan bersama".

Kepemimpinan adalah kemampuan seseorang untuk mempengaruhi, memotivasi orang lain untuk dapat memberikan kontribusi menuju tercapainya efektifitas dan kesuksesan organisasi. Robbin (2008) menyatakan kepemimpinan adalah kemampuan untuk mempengaruhi suatu kelompok guna mencapai sebuah visi atau serangkaian tujuan yang ditetapkan. Beliau menambahkan ada empat pendekatan untuk membuat pemimpin menjadi efektif: 1) Berusaha mencari ciri kepribadian universal yang derajatnya satu tingkat lebih tinggi dibandingkan dengan yang bukan pemimpin, 2) Mencoba menjelaskan kepemimpinan dan perilaku seseorang yang terlibat di dalamnya. Kedua pendekatan ini telah dicap sebagai "awal yang palsu," yang didasarkan pada konsepsi tentang kepemimpinan yang keliru dan terlalu disederhanakan, 3) Menggunakan model-model kemungkinan untuk menjelaskan tidak memadainya teori-teori kepemimpinan sebelumnya dalam merujukkan dan memadukan aneka ragam penemuan penelitian, dan 4) Perhatian kembali ke ciri, tetapi dari suatu perspektif yang berbeda. Garis pemikiran ini mengemukakan bahwa hakikat kepemimpinan adalah gaya yang menonjolkan penampilan sebagai pemimpin.

\section{METODE PENELITIAN}

Metode penelitian ini adalah penelitian kuantitatif. Populasi dalam penelitian ini adalah seluruh Mahasiswa Prodi Administrasi Pendidikan STKIP Budi Daya Binjai sebanyak 35 Orang. Data yang diperoleh dianalisis dengan menggunakan teknik statistik yakni uji persyaratan analisis data dan pengujian hipotesi. Dalam hal ini menggunakan bantuan komputer program SPSS 16.

\section{HASIL DAN PEMBAHASAN}

Hasil analisis menunjukkan bahwa kondisi motivasi berprestasi mahasiswa tinggi, sedangkan unsur yang dijadikan ukuran untuk menilai motivasi berprestasi mahasiswa adalah unsur-unsur yang meliputi pekerjaan/aktivitas mahasiswa itu sendiri, kesempatan berprestasi, tanggung jawab, pengakuan atau penghargaan, kemajuan, status pekerjaan/aktivitas, kondisi, hubungan dengan kakak tingkat dan teman seangkatan, supervisi, keamanan, kebijaksanaan. Motivasi berprestasi mahasiswa tinggi, hal tersebut tak terlepas dari persepsinya terhadap pelaksanaan diklat kepemimpinan yang bagus yaitu selain mempunyai dampak langsung yang tinggi terhadap aktivitas mahasiswa sehari-hari juga mempunyai dampak tidak langsung yang tinggi terhadap masa depan mahasiswa. Jadi karena diklat kepemimpinan mempunyai dampak yang tinggi terhadap aktivitas mahasiswa, maka membuat para mahasiswa terpacu untuk melaksanakan tugas dan aktivitasnya sebaik mungkin. Apalagi diklat kepemimpinan tidak semata-mata membuat mahasiswa untuk melaksanakan tugas dan aktivitasnya dengan sebaik-baiknya saja namun diklat kepemimpinan juga memperhatikan kebutuhan kompetensi dimasa depan. Ini merupakan suatu bentuk hasil dan manfaat dari diklat kepemimpinan terhadap mahasiswa, bahwa mahasiswa adalah manusia biasa yang memiliki kebutuhan untuk hidup dan berkembang. Hal ini juga merupakan salah satu 
pendorong bagi mahasiswa agar memiliki motivasi berprestasi yang baik dan unggul.

Hasil penelitian menunjukkan pengaruh kepemimpinan terhadap motivasi berprestasi mahasiswa sebesar $0,184(18,4 \%)$ pada taraf $\alpha=0,05$. Temuan ini akan membuat mahasiswa merasa lebih diperhatikan, dilibatkan, dan dihargai, sehingga muncul emosi positif yang mendorong tingkah laku mahasiswa menjadi lebih terarah, lebih kreatif, inovatif, dan lebih berprestasi dalamproses pembelajaran. Hal senada dengan pendapat Hasibuan (1996) menyatakan bahwa tujuan pemberian motivasi adalah: 1) mendorong gairah dan semangat kerja, 2) meningkatkan moral dan semangat kerja, 3) meningkatkan produktifitas kerja, 4) mempertahankan loyalitas dan kestabilan bawahan, 5) meningkatkan kedisiplinan dan menurunkan tingkat absensi, 6) mengefektifkan pengadaan tenaga kerja, 7) menciptakan suasana dan hubungan kerja yang baik, 8) meningkatkan kreatifitas dan partisipasi, 9) meningkatkan tingkat kesejahteraan, 10) mempertinggi rasa tanggung jawab terhadap tugas-tugas, 11) meningkatkan efisiensi pengunaan alat-alat dan bahan baku..

\section{PENUTUP}

Berdasarkan data dan hasil analisis data dapat ditarik kesimpulkan bahwa terdapat pengaruh kepemimpinan terhadap motivasi berprestasi mahasiswa sebesar 0,184 $(18,4 \%)$ pada taraf $\alpha=0,05$. Dan juga hasil analisis menunjukkan bahwa kondisi motivasi berprestasi mahasiswa tinggi.

\section{DAFTAR PUSTAKA}

Colquit Jason A., Jeffry A.LePine, Michael J. Wesson. 2009. Organizational Behaviour: Improving performance and commitment in the workplace. New York: the McGrawHill Companies.

Fullan, M. 2004. Leading in a culture of change. First Edition. U.S.A: Jossy-Bass
Hasibuan, M.S.P. 2005. Organisasi dan Motivasi. Jakarta: Bumi Aksara.

McClelland, D.C. 1987. Human Motivation. Diterjemahkan oleh Handoko. Jakarta: Salemba Empat.

Northouse, Peter G. 2013. Leadership Theory and Practice Six Edition. Los Angeles: Sage Publication.

Sagala, Syaiful. 2009. Manajemen Stratejik Dalam Peningkatan Mutu Pendidikan. Bandung : Alfabeta.

Yukl Gary. 2009. Kepemimpinan dalam Organisasi. Edisi 5. Alih Bahasa Budi Suprianto. Jakarta: Indeks.

Yunus, Mohamad. 2007. Dasar-dasar Motivasi Kerja. Jakarta: Penerbit: Universitas Terbuka. 